\title{
Seismic Effects on a Horizontally Unsymmetrical Building using Response Spectrum Analysis
}

\author{
Zafarullah Nizamani ${ }^{*}, 1$, Seah Kay Seng ${ }^{1}$, Akihiko Nakayama ${ }^{1}$, \\ Mohamad Shariff Bin Omar Khan ${ }^{1}$, and Haider Bilal ${ }^{1}$ \\ ${ }^{1}$ Environmental Engineering Department, Faculty of Engineering and Green Technology, Jalan \\ Universiti, 31900, Kampar, Malaysia
}

\begin{abstract}
Most of the residential buildings in Malaysia are not designed to withstand the seismic forces, while the high-rise buildings. However, since the Sumatra 2004 earthquake, there had been increasing concerns about the structure vulnerability in our country to earthquakes. Several recent studies had also revealed that Malaysia had the possibility to be influenced by both local and far field earthquakes. This study is conducted to analyze the vulnerability of a high rise building to local and far field earthquakes using Scia Engineer. Modal Response Spectrum method of Scia Engineer is used. The model is a 12 story hotel building from Ipoh, Perak. The designing code is the Eurocode with Malaysia Annex. Different Peak Ground Accelerations (PGA) that represents the local and far field earthquakes is acted on the model to obtain the seismic performance. The deformation of the building by the seismic combinations is compared to the ASCE-7 design to evaluate the vulnerability. Research of seismic performance of the flat slab system is also conducted along with beam frame system. The result shows that the building is in a safe condition in terms of deformation and the seismic performance of the flat slab system is advantageous.
\end{abstract}

\section{Introduction}

With the escalated number of high rise building in Malaysia, ignoring the seismic design is starting to become an arguable point by design engineers in Malaysia. To ensure that the newly constructed buildings are able to keep themselves safe from the damages of the earthquakes, a detailed understanding in the earthquake effects should be proceeded by the local engineers according to the local design annex to EC8 code. Most of the residential buildings in Malaysia are not designed to withstand the seismic waves while the high-rise buildings are only designed to resist the wind loads [1]. To be fair, the designing code that was implemented in most of the countries in South East Asia was British Standard, a code that doesn't include any conditions for the earthquakes, which explained the behavior of the local engineers and architects [2].

*Corresponding author: zafarullah@utar.edu.my 
The study covers the research of the effects of the seismic loading on high rise building. The study covers local and far field earthquake loads using Scia engineer software. The high rise buildings are two 12 storey hotel with flat slab and beams column system. The building taken in this research are hotels located in Ipoh, Malaysia. Earthquake loads are calculated based on local standard design annex to EC8 as proposed by Institute of Engineers Malaysia (IEM). Two models differ by the type of structure i.e. flat slab and beam column model. The coefficients, method of calculations used are based on the European code and Malaysian Annex.

\section{Background}

The earthquakes that affect Malaysia land are clarified into 2 types, the far field, and the local earthquake. Until some time ago, the only concern on the Malaysia underground actions were the far field earthquakes since Malaysia sits on a low-to-moderate seismicity region. The local seismicity in both Peninsular Malaysia and Singapore are so low that all the past ground movements felt in 50 years back then are all from the distant earthquake that occurs in Sumatra, Indonesia [3 and 4]. However, the local earthquake in Peninsular Malaysia had also started to be felt since past few years after the mega earthquake which occurred at Sumatra, 2004 [5]. These earthquakes which originated from the local faults (mostly at Bukit Tinggi fault) should be kept in view since the local earthquakes might be affecting on the future designs of the buildings [5].

Far field earthquakes that are felt in Malaysia can be divided into 2 sources. The first source is Sumatran subduction zone. This zone is responsible for any earthquake that occurs near the region where the Eurasian plate overrides the Indo-Australian plate which is being sub-ducted [6]. The zone is $600 \mathrm{~km}$ far from Singapore and its overall convergence rate is $7.7 \mathrm{~cm} /$ year. The highest magnitude of far field earthquake that was felt in Malaysia was 7.5 on the Richter scale, which occurred on 30 September 2009. The earthquake originated from Southern Sumatra and was $758 \mathrm{~km}$ far from Kuala Lumpur with an occurrence depth of $91 \mathrm{~km}$ into the ground. East Malaysia is classified as a moderately seismic active region due to its potential to create local earthquakes that could reach up to magnitude 5.8 on the Richter scale. As the result, Malaysia had to face the worse earthquake disaster in the history. At the date of 5 June 2015, an earthquake with magnitude 6.0 at the depth of $10 \mathrm{~km}$ had struck Ranau, Sabah. The earthquake epicentre was located near to Mount Kinabalu and had lasted long for 30 seconds [7]. The earthquake had caused 18 causalities, heavy landslides and estimated more than RM100 million property losses, crowning the earthquake to become the worse earthquake-related incident [8].

Peak Ground Accelerations or PGA is the maximum ground acceleration that is emitted in an earthquake event. It is an important parameter used in the earthquake design and the main factor for the software Scia Engineer to create the response spectrum in this research. Some researchers had conducted analysis on the PGA values for the local and far field earthquake events that had stated. According to Adnan et al. the PGA for the far field earthquakes will be 80-100 gal in Kuala Lumpur for 500 years return period [9]; According to Peterson et al. a value of 40-120 gal [10]; and Manafizad et al proposed it as 1-191gals. The unit $1 \mathrm{gal}$ is equals to $1 \mathrm{~cm} / \mathrm{s}^{2}$ [11]. For the local earthquakes, $0.08 \mathrm{~g}$ is recommended for Peninsular Malaysia and Sarawak and $0.16 \mathrm{~g}$ for [12]. Table 1 shows the PGA values of the respective studies. 
Table 1. Comparison between far field and local earthquakes

\begin{tabular}{|c|c|c|}
\hline Type & PGA & Description \\
\hline \multirow{3}{*}{ Far Field } & $80-100 \mathrm{gal} 1$ & {$[9]$} \\
\cline { 2 - 3 } & $40-120 \mathrm{gal}$ & {$[10]$} \\
\cline { 2 - 3 } & $1-191 \mathrm{gal}$ & {$[11]$} \\
\hline \multirow{3}{*}{ Local } & $0.08 \mathrm{~g} 2$ & PGA for Peninsular Malaysia according to the Malaysia National \\
& & \begin{tabular}{c} 
Annex 2015 \\
\cline { 2 - 3 }
\end{tabular} \\
\cline { 2 - 3 } & $0.16 \mathrm{~g}$ & $\begin{array}{c}\text { PGA for Sabah Sarawak according to the Malaysia National Annex } \\
2015\end{array}$ \\
\hline
\end{tabular}

\subsection{Flat Slab System}

According to Erberik and Elnashai, the fragility curve of the flat slab system is actually showing that the slab is more vulnerable to seismic damages as compared to the normal moment frames, which is because of the insufficient lateral resistant [13]. Another research by More had shown that the drifting of a flat slab system in an earthquake will be approximating to be the same with the grid floor system at the first 4 floors; however, when the story increases, the flat slab system is told to be having about $8 \%$ more drifting as compared to the grid floor. The shear experienced is also higher in the flat slab system [14]. The model analysis by Apolstolska had also mentioned that the slab system could be a contributing member, which increases the vulnerability of the building by seismic effects more than the normal buildings [15]. But, Joshi had present that the base shear in the system is still lower as compared to the conventional beam column buildings due to its flexibility [16].

\section{Methodology}

A hotel building with 2 different types of the support system is used to compare their performance under the same seismic load. Model 1 is supported by flat slab and Model 2 is by beam and columns. Both models share the same parameter, appearance, and will experience the same loading, except for self-weight. Here same parameters mean that properties of the material, cross-sections of the structural members and overall geometry of the structure remained same. The support conditions of the buildings are assumed to be fixed, with a gravel soil land condition. The method of analysis is the Response Spectrum Method.

The building that is a 12 storey hotel located in Ipoh, Perak. The reason for selecting the building is because of the availability of the hotel's geometry, which could produce a more realistic result and be a better reference for future use. The hotel is located in Jalan Dato' Lau Pak Kuan, Mukim Hulu Kinta, Ipoh, Perak. It is a trapezoidal shaped structure which has 150 units of hotel rooms, 42 suite, 2 restaurants and 2 shops. The dimensions of the hotel are $65.525 \mathrm{~m}$ in length, $40 \mathrm{~m}$ in height and $25.3 \mathrm{~m}$ at the long edge and $11.725 \mathrm{~m}$ for the short edge in width. The first 2 floors of the hotel are the hotel lobby area along with some shops and dining area. Starting from level 3 to 11 , it will be the typical floors where the hotel rooms are located. The height of the first 2 floors is $4.5 \mathrm{~m}$ and the remaining floors will be $3.1 \mathrm{~m}$ each. The hotel rooms are separated by its grade, which the left side of the building is the service suites and the right side is the normal rooms. Some minor changes to the rooms are implemented in level 8 to 11 for the suites and only level 11 for the normal 
ones. Lastly, level 12 will be the office floor where 7 office rooms are built as shown in Figure 1.

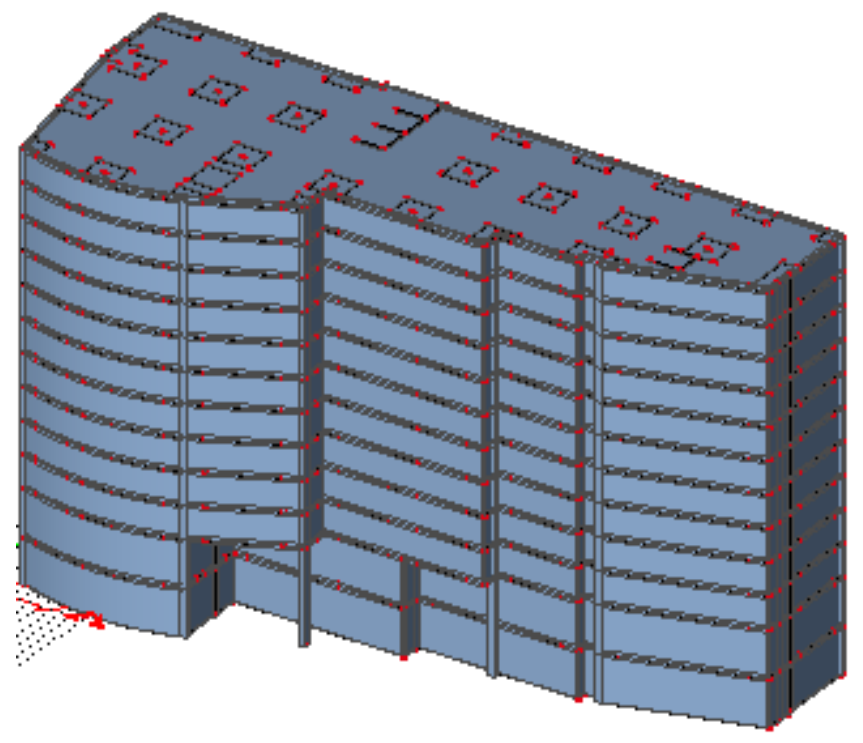

Fig. 1. Overview of the hotel model in Scia Engineer

\subsection{Seismic Load}

The Seismic loading is the main loading in this study, in which it is separated into $\mathrm{x}$ and $\mathrm{y}-$ direction to determine which direction brings the most damage to the buildings. Analysing method is response spectrum with Complete Quadratic Combination (CQC) model combinations method. All the parameters of the seismic spectrum that is drawn by the software are inputted manually according to the Eurocode 8 standard. The model will first experience 2 different level of seismic loading acceleration that is obtained from the Malaysian Standard of earthquake design, which is $0.08 \mathrm{~g}\left(0.7848 \mathrm{~ms}^{-2}\right)$ and $0.16 \mathrm{~g}$ $\left(1.5695 \mathrm{~ms}^{-2}\right)$ as the local earthquake loading; subsequently, acceleration of 191 gal (1.91 $\mathrm{ms}^{-2}$ ) which is obtained by journal from [11], will then be applied as the far field earthquake loading. The results are compared based on their base shear, story shear, bending moment, and the displacement of the stories. Figure 2, shows the respective response spectrum of the accelerations and Tables 2 will show the properties.

Table 2. Seismic loading for $0.08 \mathrm{~g}$ acceleration [12]

\begin{tabular}{|c|c|c|}
\hline Parameter & Value & Description \\
\hline Damping Ratio & 0.05 & - \\
\hline Spectrum Type & 2 & $\begin{array}{c}\text { Surface-wave magnitude, } \\
\text { Ms, not greater than 5.5 }\end{array}$ \\
\hline Ground Type & B & Gravel soil \\
\hline PGA, $\mathrm{ag}_{\mathrm{g}}\left(\mathrm{ms}^{-2}\right)$ & $0.7848(0.08 \mathrm{~g})$ & $\begin{array}{c}\text { Malaysian Standard for } \\
\text { Peninsular Malaysia. }\end{array}$ \\
\hline Beta, $\beta$ & 0.2 & - \\
\hline Behavior factor, $\mathrm{q}$ & 2 & - \\
\hline
\end{tabular}




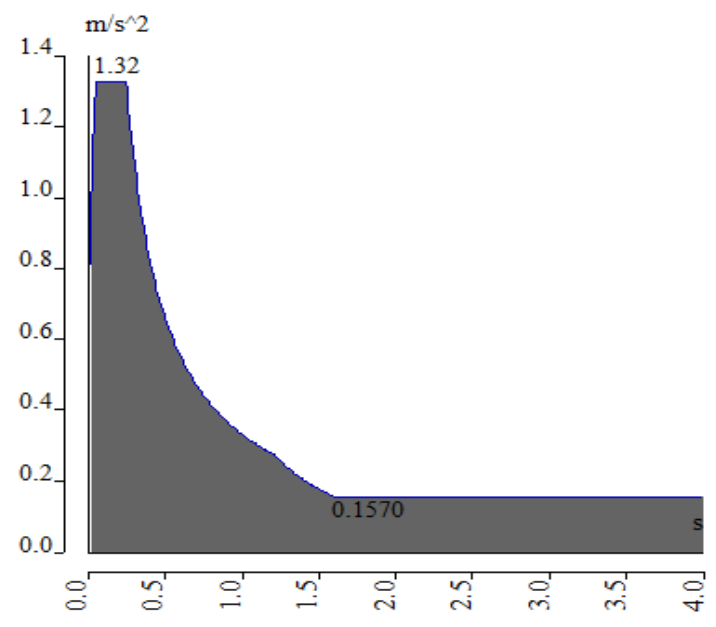

Fig. 2. Response Spectrum Curve for 0.08g acceleration.

\section{Result and Discussion}

\subsection{Response Spectrum Analysis}

The response spectrum analysis is done by applying the earthquake loads in the $\mathrm{x}$ and $\mathrm{y}$ direction, the force caused by the earthquake is then compared. The aim of this process is to identify the direction that will cause the maximum damage. With one seismic spectrum, there will be 2 seismic load case used in this analysis ( $\mathrm{x}$ and $\mathrm{y}$ - direction), without counting the accidental eccentricity which is added to the load combination analysis. The modal response spectrum analysis is required to fulfil some rules to allow the analysis to be done, which is, effective mode mass $>90 \%$ of the total structure mass. To fulfil the $90 \%$ rule, the model had been assigned with 50 Eigen modes with the Improved Reduce System (IRS) method enabled in the software. The IRS method is a function of Scia engineer that eliminates the irrelevant, local bending vibration modes from the model. With the IRS method enabled, the software will not include the irrelevant modes when undergoing the seismic calculations, which reduces the total model mass and improves the percentage weight that the Eigen modes occupy. The IRS method is also a requirement to activate the accidental eccentricity function in the software. The total sum of the effective mode mass for both models is shown in Table 3 , where $\mathrm{W}_{\mathrm{xi}}$ and $\mathrm{W}_{\mathrm{yi}}$ is the weight of mode $\mathrm{i}$ in $\mathrm{x}$ and $\mathrm{y}$ direction, $\mathrm{W}_{\mathrm{xtot}}$ and $\mathrm{W}_{\mathrm{ytot}}$ are the total weight of the mode $\mathrm{i}$ in $\mathrm{x}$ and $\mathrm{y}$ - direction.

Table 3. The participating mode mass in both models

\begin{tabular}{|c|c|c|}
\hline Model & $\mathrm{W}_{\mathrm{xi}} / \mathrm{W}_{\mathrm{xtot}}$ & $\mathrm{W}_{\mathrm{yi}} / \mathrm{W}_{\mathrm{ytot}}$ \\
\hline Flat Slab & $93.42 \%$ & $92.63 \%$ \\
\hline Beam Column & $93.07 \%$ & $92.19 \%$ \\
\hline
\end{tabular}

\subsection{Base Shear}

Figure 3 shows that the increase pattern of the base shear tends to be following the ratio of 1:1, for an instant, when the PGA is doubled, the base shear is also doubled. Subsequently, 
higher base shear is observed to be acting on beam column model, where both of them have the highest base shear experienced in the $\mathrm{X}$ direction.

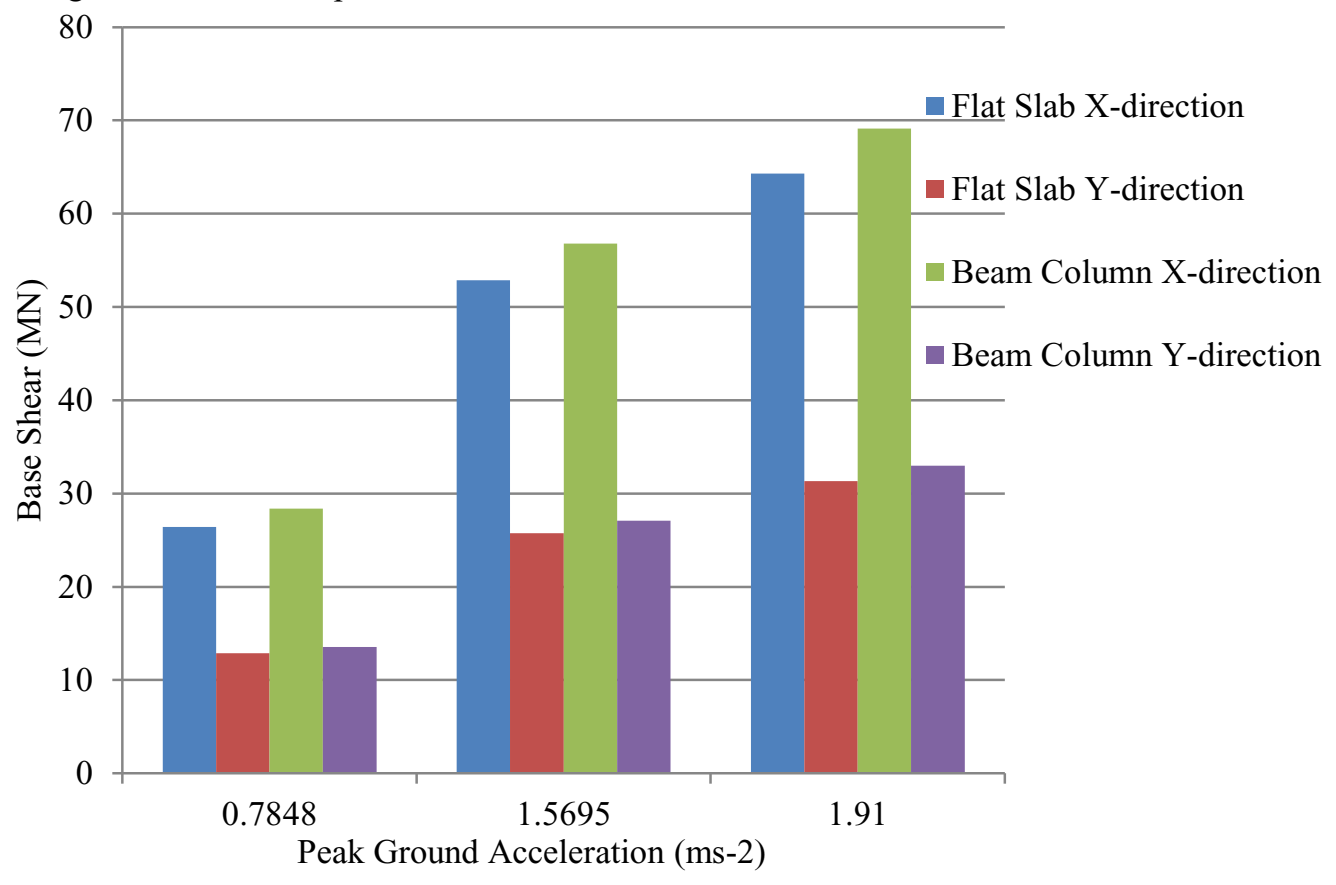

Fig. 3. Base Shear Vs Peak Ground Acceleration Graph

\subsection{Shear Force and Moment}

Tables 4 comprise of the reaction forces of the flat slab and beam column model under the seismic acceleration and loading direction. The shear force and moment of the two models at different story height are listed and compared.

Table 4. Story Shear and Moment of the models under Peak Ground Acceleration 0.08g $(0.7848 \mathrm{~ms}-$

2) in $\mathrm{X}$ and $\mathrm{Y}$ direction

\begin{tabular}{|c|c|c|c|c|c|c|c|c|}
\hline \multicolumn{5}{|c|}{$\mathrm{X}$-direction } & \multicolumn{4}{|c|}{ Y-direction } \\
\hline \multicolumn{3}{|c|}{ Flat Slab Model } & \multicolumn{2}{|c|}{$\begin{array}{c}\text { Beam Column } \\
\text { Model }\end{array}$} & \multicolumn{2}{|c|}{ Flat Slab Model } & \multicolumn{2}{|c|}{$\begin{array}{c}\text { Beam Column } \\
\text { Model }\end{array}$} \\
\hline Story & $\begin{array}{l}\text { Shear } \\
(\mathrm{MN})\end{array}$ & $\begin{array}{l}\text { Moment } \\
(\mathrm{MNm})\end{array}$ & $\begin{array}{l}\text { Shear } \\
(\mathrm{MN})\end{array}$ & $\begin{array}{l}\text { Moment } \\
(\mathrm{MNm})\end{array}$ & $\begin{array}{l}\text { Shear } \\
(\mathrm{MN})\end{array}$ & $\begin{array}{l}\text { Moment } \\
(\mathrm{MNm})\end{array}$ & $\begin{array}{l}\text { Shear } \\
(\mathrm{MN})\end{array}$ & $\begin{array}{l}\text { Moment } \\
(\mathrm{MNm})\end{array}$ \\
\hline 1 & 27 & 735 & 29 & 796 & 13 & 307 & 13 & 324 \\
\hline 2 & 25 & 610 & 26 & 660 & 19 & 248 & 12 & 262 \\
\hline 3 & 23 & 514 & 25 & 554 & 11 & 210 & 12 & 221 \\
\hline 4 & 22 & 437 & 24 & 470 & 11 & 177 & 11 & 187 \\
\hline 5 & 20 & 363 & 22 & 390 & 10 & 146 & 10 & 155 \\
\hline
\end{tabular}




\begin{tabular}{c|c|c|c|c|c|c|c|c|}
\hline 6 & 19 & 293 & 20 & 315 & 9 & 118 & 10 & 125 \\
\hline 7 & 17 & 229 & 18 & 245 & 8 & 91 & 9 & 97 \\
\hline 8 & 14 & 170 & 15 & 182 & 7 & 67 & 8 & 71 \\
\hline 9 & 12 & 119 & 13 & 127 & 6 & 45 & 7 & 48 \\
\hline 10 & 9 & 76 & 10 & 81 & 5 & 27 & 6 & 29 \\
\hline 11 & 6 & 41 & 6 & 43 & 4 & 12 & 4 & 13 \\
\hline 12 & 3 & 12 & 3 & 14 & 2 & 3 & 2 & 4 \\
\hline
\end{tabular}

It is noticed that the shear force is reducing along the story height, in which the highest shear is experienced at the ground level. Moreover, the resulting pattern of the story shear is rather similar to the predefined base shear result, in which the shear is found to be higher in the X-directions. On the other hand, the moment is discovered to be the highest at the $\mathrm{Y}$ direction (My), in the $\mathrm{X}$-direction seismic acceleration, and is following the trend to decrease when the story height is increased. Comparison of the results between the models is shown in Figures 4 show the shear force and Figure 5 the moment.

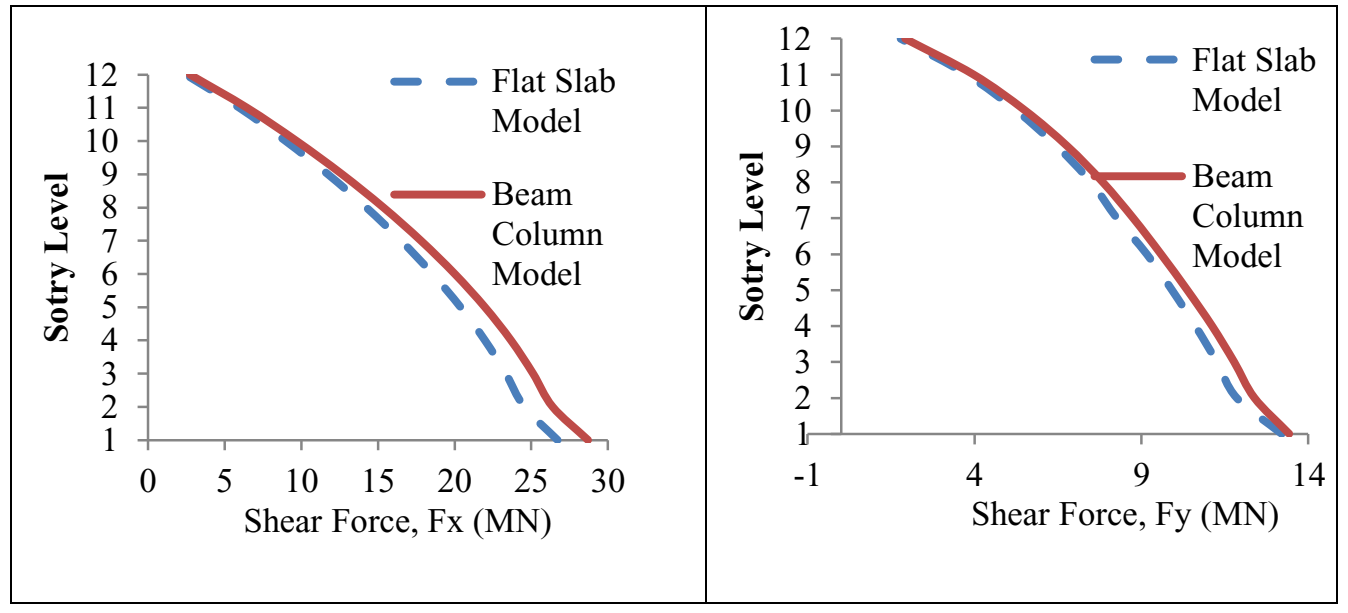

Fig. 4. Comparison of the model story shear under $0.7848 \mathrm{~ms}^{-2}$ acceleration in X-Y direction 


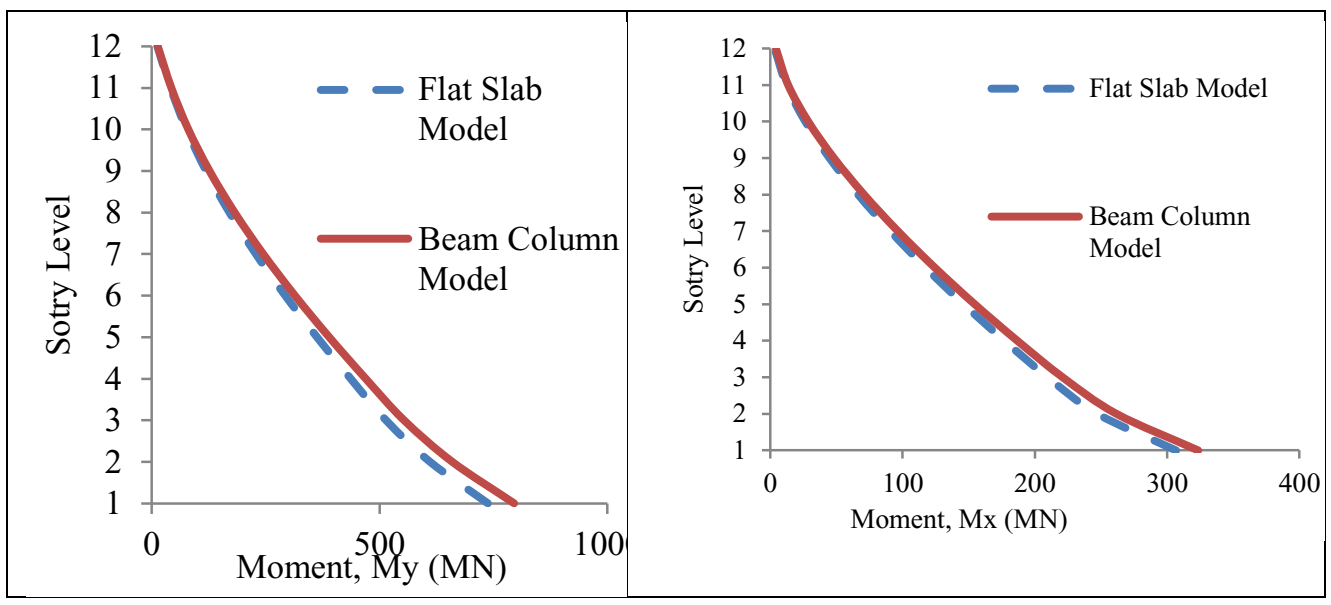

Fig. 5. Comparison of the model story moment under $0.7848 \mathrm{~ms}-2$ acceleration in $\mathrm{x}-\mathrm{y}$ direction

\section{Discussion}

Results and findings suggested that the response spectrum analysis is a simple way to explore the nonlinear behaviour of building. Response spectrum analysis can identify weak elements by predicting the failure mechanism and account for the redistribution of forces during progressive yielding. It may help engineers take action for rehabilitation work.

Moreover, Base shear is quite high in beam column frame structure as compared to flat slab structure similarly moment also behaves the same which concludes that flat slab structural buildings will provide better resistance to seismic activities and offers better safety measures.

\section{Conclusion}

It has been found that base shear, shear force, moment and deformations of a building can be affected by the type of slab system used. Flat Slab system is proved to be higher a seismic performance as compared to the normal beam column slab system. base shear, shear force and moment of the structure shows that the irregular structure had experienced higher base shear and shear force in the x-direction, while the moment had a higher response to the y-direction. Displacement of the building was found out to be significantly higher in the y-direction compared to the x-direction. The reason for the difference will be the irregularity of the structure, which causes uneven distribution of the lateral forces.

The authors acknowledge Universiti Abdul Rahman (UTAR) for the funding with Project No. IPSR/RMC/UTARRF/2016-C1/21

\section{References}

1. H. Akmal, Buildings in Malaysia not quake-resistant, (2015)

2. K.Megawati, T. K. Lam, M. Chandler, T. S. Pan, Cities without Seismic Code I: Hazard Assessment. 13th World Conference on Earthquake Engineering, Paper 129, (2004) 
3. K. Megawati, and T. S. Pan, Ground-motion attenuation relationship for the Sumatran megathrust earthquakes. Earthquake Engineering and Structure Dynamics, 39, 827-845. (2009)

4. K., S. Mustaffa, The recent Bukit Tinggi earthquakes and their relationship to major geological structures. Bulletin of the Geological Society of Malaysia, 55, pp 67-72. (2009)

5. A., B. Nabilah, Vulnerability of gravity load designed building against far field earthquake (2015).

6. T. Balendra, \& Z. Li, Seismic Hazard of Singapore and Malaysia. Electronic Journal of Structural Engineering, 57-63. (2008)

7. Borneo Post Online. 6.0 trembler rattles Sabah west coast. (2015)

8. Malaymail Online. Sabah earthquake a 2015 shock for the nation. (2015)

9. A. Adnan, Hendriyawan, A. Marto, and M.Irsyam,. Development of seismic hazard map for Peninsular Malaysia. Proceeding on Malaysian Science and Technology Congress. PWTC, Kuala Lumpur, Malaysia. (2006)

10. M. D. Petersen, J. Dewey, S. Hartzell, , C. Mueller, S. Harmsen, A. D. Frankel, Probabilistic seismic hazard analysis for Sumatra, Indonesia and across the southern Malaysian Peninsula. Tectonophysics, 390, 141-158. (2004)

11. A. N. Manafizad, B. Pradhan, , S. Abdullahi, , 2016. Estimation of Peak Ground Acceleration (PGA) for Peninsular Malaysia using geospatial approach. IOP Conf. Series: Earth and Environmental Science 37, (2016)

12. Malaysia Standard National Annex-EN 1998-1. Eurocode 8: Design of structures for earthquake resistance - Part 1: General rules, seismic actions and rules for buildings. Department of Standards Malaysia. (2016)

13. M. A. Erberik, A., S. Elnashai, , Seismic Vulnerability of Flat-Slab Structures. Technical Report Mid-America Earthquake Center DS-9 Project (Risk Assessment Modeling). (2003)

14. R. S. More, V, S. Sawant, Y., R. Suryawanshi, Analytical Study of Different Types of Flat Slab Subjected to Dynamic Loading, International Journal of Science and Research (IJSR) 4, 7. (2013)

15. R. P. Apostolska, , G. S. N. Cvetanovska, , J. P Cvetanovska, N. Mircic., Seismic Performance of Flat-Slab Building Structural Systems. The 14th World Conference on Earthquake Engineering. (2008)

16. D. D. Joshi, B. M. Pranesh, Performance of Flat Slab Structure Using Pushover Analysis. IOSR Journal of Mechanical and Civil Engineering (IOSR-JMCE) eISSN: 2278-1684, 8, 3, (2013) 